\title{
Effects of Diet Protein Level on Growing- Finishing Pig Performance in a Tropical Environment ${ }^{1}$
}

\author{
J. Le Dividich and I. Canope ${ }^{2}$
}

\begin{abstract}
The effect of increasing the dietary crude protein (CP) level on the growth performance and carcass characteristics of Large White pigs reared in Guadeloupe under tropical climatic conditions was determined. Test animals included 32 females and 32 barrows, each weighing about $24 \mathrm{~kg}$ initially. They were individually fed one of four test diets based on corn and soybean-oil meal containing $12,16,20$, and $24 \% \mathrm{CP}$, respectively. The 12 and $16 \% \mathrm{CP}$ diets were supplemented with synthetic L-lysine hydrochloride. The animals were slaughtered at $95 \mathrm{~kg}$ liveweight.

On the basis of maximum daily gain and minimum feed conversion ratio, the best level of CP among the various levels compared was $16 \%$ for the growing pigs (from 24 to $60 \mathrm{~kg}$ liveweight) and $12 \%$ for the finishing pigs (from $60 \mathrm{~kg}$ to $95 \mathrm{~kg}$ liveweight). There was no significant effect of sex on growth performance, but the feed conversion ratio of the finishing females was $8 \%$ better than that of the barrows. As the dietary $\mathrm{CP}$ level increased, dressing percentage and backfat thickness decreased linearly $(P<0.05)$. Females were significantly leaner $(P<$ 0.05 ) than barrows. Further work is needed to determine the optimum level of CP for finishing pigs.
\end{abstract}

\section{INTRODUCTION}

During the past 20 years, considerable attention has been paid to determination of the optimum crude protein level in diets for pigs reared in the temperate countries $(1,7,19,21)$. In contrast, less such information is available for tropical countries $(2,9)$. However, because of the reduction in feed intake $(5,11)$ and probable increase in urinary nitrogen losses $(14$, 15) occurring at high ambient temperatures, recommendations emanating from temperate countries may not be necessarily applicable to pigs raised in tropical climatic conditions. In addition, the optimum crude protein level varies according to various criteria (daily weight gain, nitrogen retention, body composition, and quality of protein used) (21). Thus, results reported by Babatunde et al. (2) suggest that the optimum crude protein level in diets for weaning and growing pigs is higher than that recommended for temperate countries. Nevertheless, it is difficult to generalize these results, which have been obtained with diets based on local feedstuffs, whose nutritive value is variable.

${ }^{1}$ Manuscript submitted to Editorial Board December 12, 1976.

${ }^{2}$ Animal nutritionist, Centre de Recherches Agronomiques des Antilles et de la Guyane, Station de Recherches Zootechniques, Guadeloupe; present address: I.N.R.A Jouy C.N.R.Z. Station de Recherches sur l'Elevage des Porcs-78350 Jouy-en-Josas. France; and Animal nutritionist, Centre de Recherches Agronomiques des Antilles et de la Guyane, Station de Recherches Zootechniques, Guadeloupe. Thanks are due to E. Calif, E. Despois, and F. Hedreville for their technical assistance. 
The present experiment was designed to study the effect of increasing the dietary crude protein level on the performance of growing-finishing pigs reared in Guadeloupe (West-Indies) when fed diets based on corn and soybean meal, which are commonly used in both American and European temperate countries.

\section{MATERIALS AND METHODS}

\section{CLIMATE}

Relevant climatic data for the experiment (November 1973 to July 1974) were as follows: average minimum and maximum temperatures were $20.5^{\circ} \mathrm{C}$ and $27.5^{\circ} \mathrm{C}$, respectively, with a mean of $24^{\circ} \mathrm{C}$; average minimum humidity was $70 \%$, while the maximum was always between 95 and $100 \%$ during the night. Total hours of bright sunshine averaged 180 $\mathrm{h} / \mathrm{mo}$ (range $160 \mathrm{~h}$ in December to $192 \mathrm{~h}$ in April), and monthly rainfall was about $223 \mathrm{~mm}$ (range $98 \mathrm{~mm}$ in February to $405 \mathrm{~mm}$ in May). These data were recorded at the Bioclimatological Research Station of the Agronomical Research Center located about $300 \mathrm{~m}$ from the place of the present experiment.

\section{HOUSING}

All pigs were group-housed on concrete-floored pens. Each pen was divided into two areas: a dry sleeping area $1.5 \times 2.2 \mathrm{~m}$ covered with a 1.8$\mathrm{m}$ high corrugated galvanized iron roof, and with an open-front area 2.5 $\times 2.2 \mathrm{~m}$, equipped with individual feeding stalls and automatic waterers. No bedding was used.

\section{TREATMENTS}

Four test diets based on ground yellow corn and soybean-oil meal were formulated (table 1 ) to contain $12,16,20$, and $24 \%$ crude protein (CP). To the 12 and 16\% CP diets, synthetic L-Lysine hydrochloride was added at levels of 0.26 and $0.03 \%$, respectively, to satisfy the recommendations of the National Research Council (19).

\section{ANIMALS AND MANAGEMENT}

Sixty-four Large White pigs weaned at 5 weeks and reared to about 11 weeks of age, weighing initially $24.1 \pm 3.1 \mathrm{~kg}$, were assigned to 16 groups of 4 pigs each on the basis of sex and average initial weight. There were eight groups of castrated males (barrows) and eight groups of females. The animals were allocated at random within each group to each one of the four treatments. They were twice daily fed the amount they could consume in $45 \mathrm{~min}$. Water was supplied ad libitum. The pigs were weighed once every two weeks in the morning before feeding. Feed intake was recorded daily. They were slaughtered at a mean live weight of $95 \mathrm{~kg}$. After dressing and splitting the carcass into two longitudinal halves, it 
was chilled for $24 \mathrm{~h}$, after which average backfat thickness opposite the last rib and the last lumbar vertebra was measured on each half. The cold-dressing percentage was calculated as follows:

$$
\frac{\text { Cold carcass without head }(\mathrm{kg})}{\text { Liveweight }(\mathrm{kg})} \times 100
$$

All data collected were analysed according to a split plot design. Linear and quadratic terms of variance analysis were calculated according to Snedecor (24).

\section{RESULTS}

Results of average daily gain (ADG), feed intake, and feed conversion ratios (FCR) for the different weight class intervals from 24 to $95 \mathrm{~kg}$ liveweight are summarized in figures 1 and 2 , and in table 2 .

TABLE 1.-Formulation and composition of the diets

\begin{tabular}{lcccc}
\hline \multirow{2}{*}{\multicolumn{1}{c}{ Ingredients }} & \multicolumn{4}{c}{ Dietary protein level (\% as fed) } \\
\cline { 2 - 5 } & 12 & 16 & 20 & 24 \\
\hline Ground yellow maize & 78.4 & 68.0 & 56.6 & 45.1 \\
Soybean meal (44\% CP) & 7.6 & 19.0 & 30.4 & 41.9 \\
Wheat bran & 10.0 & 10.0 & 10.0 & 10.0 \\
Dicalcium phosphate & 1.4 & 1.2 & 1.0 & .8 \\
Ground limestone & 1.1 & 1.2 & 1.3 & 1.4 \\
Salt (NaCl) & .30 & .22 & .27 & .12 \\
Vitamin mix & 1.00 & 1.00 & 1.00 & 1.00 \\
Trace mineral mix ${ }^{2}$ & .20 & .20 & .20 & .20 \\
L-Lysine hydrochloride & .26 & .03 & & \\
Analysed crude protein \% & 12.2 & 16.4 & 20.5 & 25.0 \\
Analysed lysine \% & .61 & .92 & 1.10 & 1.42 \\
Analysed methionine + cystine \% & .48 & .57 & .72 & .93 \\
Calculated digestible energy & 3,330 & 3,370 & 3,390 & 3,420 \\
\multicolumn{1}{c}{ (kcal/kg diet) $^{3}$} & & & & \\
\hline
\end{tabular}

${ }^{1}$ The vitamin mixture supplied the following quantities per $\mathrm{kg}$ of mixed diet: vit. A, 4,000 I.U.; vit. D2, 1,000 I.U.; riboflavin, $2 \mathrm{mg}$; nicotinic acid, $10 \mathrm{mg}$; calcium panthothenate, $5 \mathrm{mg}$; choline, $100 \mathrm{mg}$; and vit. B12, $10 \mu \mathrm{g}$.

${ }^{2}$ The mineral mixture supplied the following quantities per $\mathrm{kg}$ of mixed diet: $\mathrm{FeSO}_{4} \cdot 7 \mathrm{H}_{2} \mathrm{O}$, $250 \mathrm{mg} ; \mathrm{ZnSO}_{4}, 310 \mathrm{mg} ; \mathrm{MnSO}_{4} \cdot \mathrm{H}_{2} \mathrm{O}, 120 \mathrm{mg} ; \mathrm{CuSO}_{4} \cdot 5 \mathrm{H}_{2} \mathrm{O}, 50 \mathrm{mg}$; stabilised $\mathrm{KI}, 2 \mathrm{mg}$; $\mathrm{CoSO}_{4} \cdot 7 \mathrm{H}_{2} \mathrm{O}, 2.4 \mathrm{mg} ; \mathrm{MgCO}_{3}, 1250 \mathrm{mg}$,

${ }^{3}$ According to Nat. Res. Counc. (19)

Between 24 and $60 \mathrm{~kg}$ liveweight (fig. 1), the shape of ADG and FCR curves according to the level of $\mathrm{CP}$ was parabolic (quadratic effect significant at the $1 \%$ level). Best ADG and FCR were obtained on the $16 \% \mathrm{CP}$ diet, but they were not significantly different from ADG and FCR on $20 \%$ CP diet. Feed consumption varied very little with the level of CP; it showed a tendency to decrease only at the highest level of CP. Sex had no significant effect on any of these criteria. 
During the finishing period (from 60 to $95 \mathrm{~kg}$ liveweight), ADG decreased and FCR increased linearly (fig. 2) when the level of CP was increased (linear effect significant at the $5 \%$ level). The highest performance was obtained with the $12 \% \mathrm{CP}$ diet: ADG dropped by $10 \%$ and FCR increased $13 \%$ when the level of CP rose from 12 to $24 \%$. Sex showed no effect on ADG, but barrows consumed about $7 \%$ more feed $(\mathrm{P}<.05)$ and required $8 \%$ more feed per unit of gain $(\mathrm{P}<.05)$ than iernales.

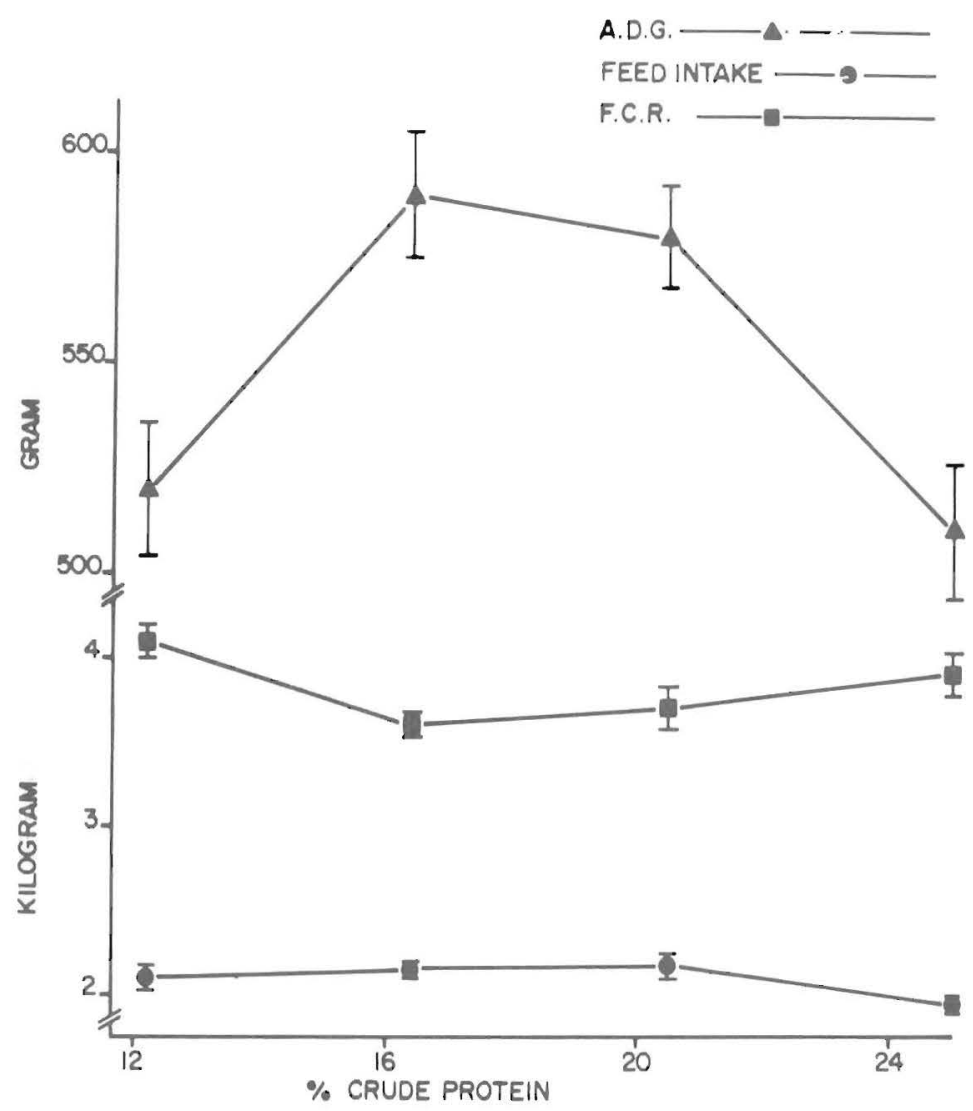

FIG. 1.-Effect of CP level on ADG (g/day), feed intake (kg/day), and FCR during the growing period (from 24 to $60 \mathrm{~kg}$ liveweight). Results are expressed as mean $\pm \mathrm{SEM}$

During the entire fattening period, the best rates of gain and FCR were achieved with the 16\% CP diet, but ADG was not significantly better than the rate of gain with the $20 \%$ protein diet; and FCR was not significantly better than the ratio of 12 and $20 \%$ protein diets. Pigs fed the $24 \% \mathrm{CP}$ diet grew slower $(\mathrm{P}<.05)$ than those fed the $16 \% \mathrm{CP}$ diet. Increase in the protein level from 12 to $16 \%$ did not significantly improve 
daily feed consumption; but increasing the protein level beyond $16 \%$ resulted in a slight decrease in daily feed intake. The difference between the means of $16 \%$ and $24 \%$ protein diets was significant $(\mathrm{P}<.05)$. Sex had no significant effect on $\mathrm{ADG}$, feed intake, and FCR.

Cold-dressing percentage and backfat thickness data are summarized in table 3. Dressing percentage decreased linearly as protein level in-

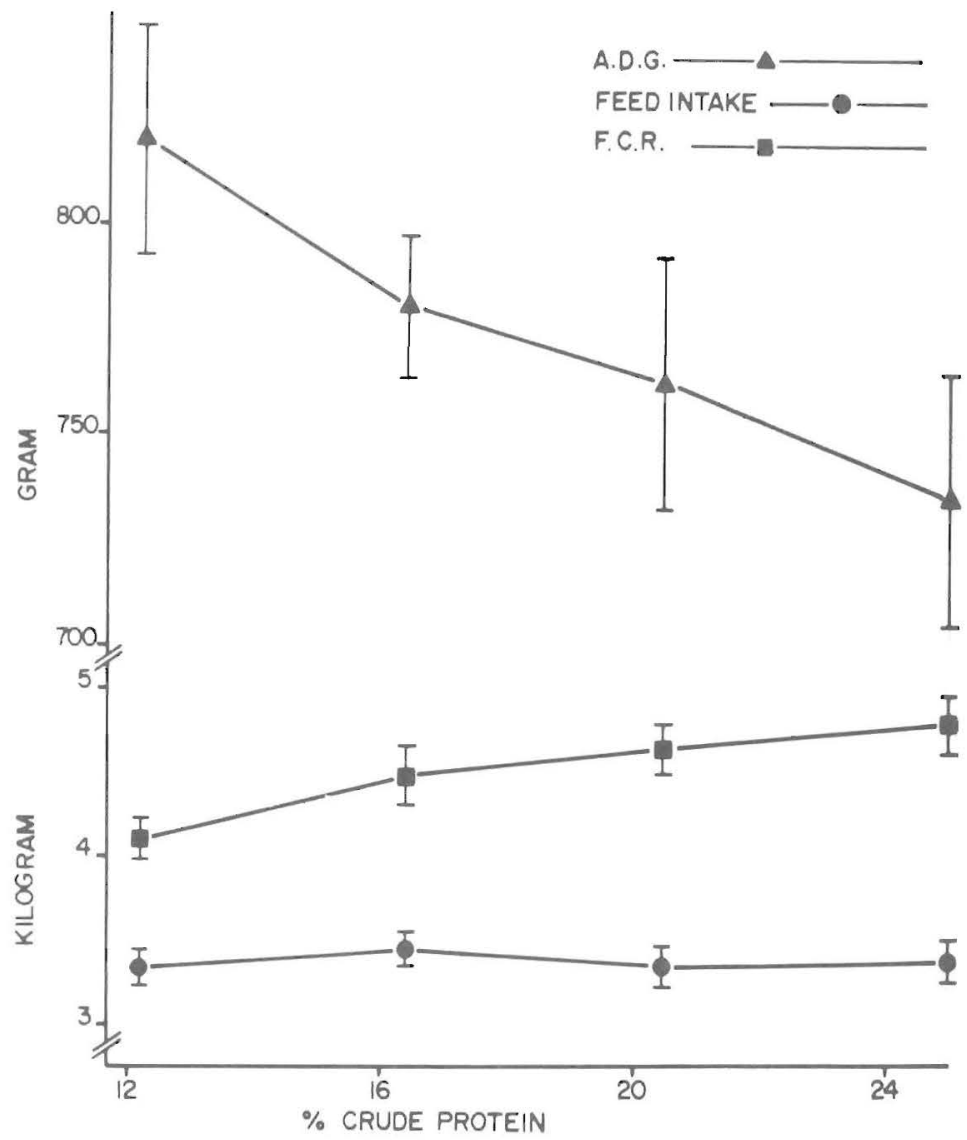

FIG. 2.-Effect of CP levels on ADG (g/day), feed intake (kg/day), and FCR during the finishing period (from 60 to $95 \mathrm{~kg}$ liveweight). Results are expressed as mean \pm SEM

creased, that of $24 \%$ protein diet being significantly lower $(\mathrm{P}<.05)$ than that observed for 12 and $16 \%$, but not for $20 \%$ protein diets. Mean backfat thickness decreased when protein levels increased. Pigs fed 16 and 20\% protein diets were significantly leaner than those fed $12 \%$ protein diet and significantly fatter $(\mathrm{P}<.05)$ than those fed $24 \%$ protein diet. Furthermore, barrows were fatter than females $(\mathrm{P}<.05)$. 
TABLE 2.-Average daily gain, feed intake and feed/gain ratios for entire fattening period (from 24 to $95 \mathrm{~kg}$ liveweight)

\begin{tabular}{|c|c|c|c|c|c|c|c|}
\hline \multirow{2}{*}{ Characteristics } & \multirow{2}{*}{$\operatorname{Sex}^{1}$} & \multicolumn{4}{|c|}{ Dietary protein level (\% as fed) } & \multirow{2}{*}{ Mean } & \multirow{2}{*}{$\begin{array}{l}\mathrm{SE} \text { of means } \\
\text { (C.V. })^{2}\end{array}$} \\
\hline & & 12 & 16 & 20 & 24 & & \\
\hline \multirow[t]{3}{*}{$\mathrm{ADG}(\mathrm{g} /$ day $)$} & $\mathrm{B}$ & 625 & 688 & 659 & 594 & 642 a & \\
\hline & $\mathrm{F}$ & 643 & 670 & 657 & 614 & $646 a$ & \\
\hline & Mean & $634 \mathrm{ac}$ & $679 \mathrm{~b}$ & $658 \mathrm{bc}$ & $604 \mathrm{a}^{3}$ & & $15.7(10.0) Q^{* *}$ \\
\hline \multirow[t]{3}{*}{ Feed intake (kg/day) } & $\mathrm{B}$ & 2.60 & 2.84 & 2.80 & 2.54 & $2.69 \mathrm{a}$ & \\
\hline & $\mathrm{F}$ & 2.58 & 2.60 & 2.66 & 2.54 & $2.60 \mathrm{a}$ & \\
\hline & Mean & $2.59 \mathrm{ac}$ & $2.72 \mathrm{ab}$ & $2.74 \mathrm{~b}$ & $2.54 \mathrm{c}$ & & $.06(8.9) Q^{*}$ \\
\hline \multirow[t]{3}{*}{ FCR } & B & 4.16 & 4.12 & 4.25 & 4.28 & $4.20 \mathrm{a}$ & \\
\hline & $\mathrm{F}$ & 4.01 & 3.88 & 4.04 & 4.14 & $4.02 \mathrm{a}$ & \\
\hline & Mean & $4.08 \mathrm{ab}$ & $4.00 \mathrm{a}$ & $4.14 \mathrm{ab}$ & $4.21 \mathrm{~b}$ & & $.06(5.7) \mathrm{Q}^{*}$ \\
\hline
\end{tabular}

${ }^{1} \mathrm{~B}$, barrow; F, female.

${ }^{2}$ C.V., coefficient of variation $\left(\frac{\mathrm{s}}{\overline{\mathrm{x}}} \times 100\right) \mathrm{L}$, linear effect. Q, Quadratic effect*, $\mathrm{P}<.05 ; * *, \mathrm{P}<.01$.

${ }^{3}$ Means followed by one or more letters in common do not differ significantly at the $5 \%$ level. 
TABLE 3.-Effect of dietary protein level on carcass characteristics

\begin{tabular}{|c|c|c|c|c|c|c|c|}
\hline \multirow{2}{*}{ Characteristics } & \multirow{2}{*}{$\operatorname{Sex}^{1}$} & \multicolumn{4}{|c|}{ Dietary protein level (\% as fed) } & \multirow{2}{*}{ Mean } & \multirow{2}{*}{ SE of means (C.V.) } \\
\hline & & 12 & 16 & 20 & 24 & & \\
\hline \multirow[t]{3}{*}{ Cold dressing percentage } & B & 72.8 & 72.6 & 72.4 & 70.8 & $72.1 \mathrm{a}^{3}$ & \\
\hline & $\mathrm{F}$ & 72.6 & 72.7 & 71.5 & 71.3 & $71.8 \mathrm{~b}$ & \\
\hline & Mean & $72.7 \mathrm{a}$ & $72.6 \mathrm{a}$ & $71.9 \mathrm{ab}$ & $71.1 \mathrm{~b}$ & & $.41(2.28) \mathrm{L}^{*}$ \\
\hline \multirow[t]{3}{*}{ Average backfat thickness (mm) } & $\mathrm{B}$ & 36.0 & 32.0 & 31.7 & 28.9 & $32.1 \mathrm{a}$ & \\
\hline & $\mathrm{F}$ & 31.1 & 30.7 & 30.7 & 28.0 & $30.1 \mathrm{~b}$ & \\
\hline & Mean & $33.6 \mathrm{a}$ & $31.3 \mathrm{~b}$ & $31.2 \mathrm{~b}$ & $28.5 \mathrm{c}$ & & $.80(10.4) \mathrm{L}^{*}$ \\
\hline
\end{tabular}

${ }^{1,2,3}$ See footnotes of table 2 . 


\section{DISCUSSION}

Generally, the ADG values reported here are fairly comparable to those found in temperate countries $(1,7,19,21)$, whereas, the FCR, data are somewhat higher. This may be due to the level of feed intake which remains high in spite of the high energy density of the diets and the climatic conditions. Results of Holmes (14), Hsia (16), and McCracken (17) also indicate that at high temperature, the FCR increases with the feed intake level. Furthermore it is suggested that energy requirements for maintenance are increased in hot climates (14).

According to the present results, on the basis of maximum daily gain and minimum FCR, the optimum (or minimum) $\mathrm{CP}$ level of diets based on corn and soybean meal is 16 and $12 \%$, respectively, for the growing and the finishing pigs reared in humid tropical conditions. Decrease in optimum CP level, relative to the energy requirement when the animals get older, is well known (21). However, because of the linear improvement of $\mathrm{ADG}$ and FCR when the level of CP decreases during the finishing period, it is possible that the optimum may be below $12 \%$ for the finishing pigs, especially for the finishing barrows. Optimum CP requirement of barrows is lower than that of females $(8,22)$. Further experiments are required to elucidate this suggestion. Present results are somewhat lower than the recommendations of Babatunde (2) in Nigeria. They are also lower than those of Devendra and Parris (9) in Trinidad, which were obtained in environmental conditions similar to those described here, but with diets based on local feedstuffs. The discrepancies noticed are probably due to the quality of the protein sources used, depending upon the composition and availability of the essential amino-acids. For similar levels of feed intake, results with the growing pig are in good agreement with the recommendations emanating from different temperate countries as reviewed by Clausen (7), ARC (1), N.R.C. (19) and Rerat (22). As for finishing pigs, the results presented are slightly lower than the corresponding recommendations for temperate countries.

The reduction of feed intake and growth performance observed with the highest level of CP supports the findings of Terril et al. (26) and Sugahara et al. (25), but not those of Rerat and Henry (22). However, judged from the decreasing rate of daily gain during the finishing period, as dietary CP level increases, pigs in hot climates seem to be more sensitive to high CP level than those reared in temperate countries. It is most likely that the heat increment arising from protein metabolism on high protein diets at high temperature increases the stress on pigs $(6,17$, 18). This may also explain that the optimum CP level for finishing pigs seems to be somewhat lower than that recommended in temperate countries. Under the semi-ad libitum feeding regime of the present study, sex effect was not significant on $\mathrm{ADG}$. But, during the finishing period, the finding that females required significantly less feed per unit of gain 
than barrows is in accordance with the results of Bowland and Berg (4), Desmoulin (8), and Henry et al. (13).

Carcass characteristics indicated that the backfat thickness decreased when dietary CP level increased. The dependance of carcass leanness on protein intake in this study is in agreement with results obtained by almost all authors of both temperate and tropical countries $(2,3,10,21)$. Decrease in fatness probably explains decrease in dressing percentage when the CP level increases, in accordance with the data of Sugahara et al. (25). On the other hand, females provide leaner carcasses than barrows. This result, which is generally explained by the ability of females to retain more dietary nitrogen than barrows (20), may also be due to the lower voluntary feed intake, as observed in females, beyond the $60 \mathrm{~kg}$ liveweight in the present study and in other reports $(12,23,27)$.

In conclusion, the present results indicate that on the basis of maximum $\mathrm{ADG}$ and minimum FCR, the optimum $\mathrm{CP}$ level for pigs reared in a humid tropical environment and fed diets based on corn and soybean meal should be $16 \%$ for the growing period and $12 \%$ or less for the finishing period. The values obtained here were somewhat lower than the recommendations of other tropical countries, probably because of the higher biological value of the protein sources used in the present study.

\section{RESUMEN}

Se investigó el efecto que podrian tener aumentos en las unidades alimentarias de proteína bruta (CP) en el crecimiento y características de la canal de cerdos de la raza LargeWhite criados en el ambiente tropical de Guadalupe. La temperatura y la humedad relativa fluctuaron entre 20.5 y $27.5^{\circ} \mathrm{C}$, y 70 y $100 \%$, respectivamente. Se usaron 32 cerdas y 32 cerdos con un peso inicial de alrededor de $24 \mathrm{~kg}$,, alojados en grupos. Dos veces al día se les suministró una de cuatro dietas experimentales. Estas consistían de maíz y harina de soja, las cuales contenían $12,16,20$ y $24 \%$, respectivamente de proteína bruta. Las dietas que contenían 12 y $16 \%$ de CP se suplementaron con hidrocloruro de L-lisina sintético. Los animales se sacrificaron cuando el peso vivo alcanzó $\operatorname{los} 95 \mathrm{~kg}$.

A base de la máxima ganancia diaria de peso y de una razón mínima de transformación del alimento, el mejor nivel de CP entre las unidades comparadas fue el de $16 \%$, para los cerdos en crecimiento (de 24 a $60 \mathrm{~kg}$ de peso vivo) y $12 \%$ para los cerdos en el último período de cebadura (de 60 a $95 \mathrm{~kg}$ ). No hubo efecto significativo en cuanto al sexo, pero la razón de transformación en la etapa final de los cerdos fue $8 \%$ mejor que en las cerdas. A medida que las unidades de CP aumentaron, el porcentaje de rendimiento a la canal y el grosor de la capa de tocino disminuyeron linealmente $(\mathrm{P}<.05)$. Las hembras eran significativamente más magras $(\mathrm{P}<.05)$ que los machos.

Es necesario continuar estas investigaciones para determinar el nivel óptimo de CP en el último período de cebadura del cerdo.

\section{LITERATURE CITED}

1. Agricultural Research Council, 1967. Nutrient requirements of Farm Livestock. No. 3 Pigs. Agric. Res. Counc. London.

2. Babatunde, G. M., Olomu, M. J., and Oyenuga, V. A., 1972. Determination of the optimum crude protein requirement of pigs in a tropical environment, Anim. Prod. 14: $57-67$.

3. Blair, R., Dent, J. B., English, P. R., and Raeburn, J. R., 1969. Protein, lysine and feed intake levels effects on pig growth. I. Main effects, J. Agric. Sci. 72: 379-400.

4. Bowland, J. P. and Berg, R. T., 1950. The influence of strain and sex on the relationship of protein to energy in the rations of growing and finishing bacon pigs, Can. J. Anim. 
Sci. 39: 102-14.

5. Brobeck, J. R., 1960. Food and temperature, Recent Prog. Horm. Res. 16: 439-66.

6. Charlet-Lery, G., 1975. Les dépenses énergétiques prandiales et postprandiales chez le porc en croissance. Thèse Doc. Univ. Paris VI, France.

7. Clausen, H., 1965. The protein requirements of growing meat type pigs, World Rev. Anim. Prod. 1: 28-42.

8. Desmoulin, B., 1969. Influence de l'alimentation restreinte sur les performances du porc: variations suivant le sexe, J. Rech. Porcine en France, 67-71, I.N.R.A.I.T.P. ed., Paris.

9. Devendra, C., and Parris, E.C.C., 1970. Optimum crude protein levels for growing and finishing pigs in a tropical environment, Trop. Anim. Health Prod. 2: 162-6.

10. Fetuga, B. L., Babatunde, G. M., and Oyenuga, V. A., 1975. Protein levels in diets for European pigs in the tropics, I. The effect of methionine supplementation on the protein requirement of growing pigs, Anim. Prod. 20: 133-46.

11. Heitman, J., Jr., Kelly, C. F., and Hugues, T. E., 1958. Ambient air temperature and weight gain in swine, J. Anim. Sci. 17: 62-7.

12. Henry, Y., Rerat A., and Tomassone, R., 1971. Lysine requirement of the growingfinishing pig. Application of the multivariate statistical analysis, Ann. Zootech. 20: $521-50$.

13. — - - 1964. Variations des taux énergétiques et azotés dans l'alimentation du porc en croissance. Observations préliminaires, Ann. Biol. Anim. Bioch. Biophys. 4: 263-71.

14. Holmes, C. W., 1973. The energy and protein metabolism of pig growing at a high ambient temperature, Anim. Prod. 16: 117-33.

15. — 1974. Further studies on the energy and protein metabolism of pig growing at a high ambient temperature, including measurements with fasting pigs, Anim. Prod. 19: 211-20.

16. Hsia, L. C., 1974. Acclimatisation of pigs to high temperature. Thesis Science, Univ. Aberdeen.

17. McCracken, K. J., 1972-1973. Interaction of nutrition and environment on fattening pigs, Agric. Res. Inst. Northern Ireland. Ann. Rep., 17-26.

18. Mazer, A., 1970. Ration protidique d'adaptation au climat tropical. Cahiers Nutr. diet, 5: $57-63$

19. Nat. Acad. Sci-Nat. Res. Counc., 1968, Nutrient requirements of domestic animals; 2. Nutrient requirements of swine, NAS-NRC Publ. 1599, Wash., D.C.

20. Nielsen, A. J., 1971. K. Vet. Landbohoejsk. Arsskk, Copenhagen, Denmark, p. 81.

21. Rerat, A., 1972. Protein nutrition and metabolism in the growing pigs, Nutr. Abst. Rev. 42: 13-39.

22. - - and Henry, Y., 1967. Étude du besoin azoté chez le porc en croissance, II. Utilisation de la farine de poisson à des doses excessives par rapport au besoin azoté, Ann. Zootech., 16: 203-11.

23. Robinson, D. W., 1966. Sex differences in the response of pigs to dietary amino-acid supplementation, with reference to growth and body composition, J. Sci. Food. Agric. 17: $1-6$.

24. Snedecor, G. W., Statistical Methods, 1956. Iowa State Coll. Press, Ames, Iowa.

25. Sugahara, M., Baker, D. H., Harmon, B. G., and Jensen, A. H., 1969. Effect of excess levels of dietary crude protein on carcass development in swine, J. Anim. Sci., 29: 598-601.

26. Terril, S. W., Warder, W. K., Becker, D. E., and Bearner, P. B., 1952. The effect of feeding a high level of crude protein in the dry lot ration of fattening hogs, J. Am. Vet. Med. Assoc. 121: 304-5.

27. Young, L. G., Ashton, G. C., Forshaw, R. P., and Ingram, R. H., 1968. Relationship of dietary protein levels to performance and carcass merit of market swine, Can. J. Anim. Sci. 48: 71-81. 